\title{
The Context of Ecuador's World Heritage, for Sustainable Development Strategies
}

\author{
Paúl C. Carrión-Mero ${ }^{1,2^{*}}$, Fernando E. Morante-Carballo ${ }^{1,4,5}$, Gricelda A. Herrera-Franco ${ }^{3}$, Alfonso Maldonado-Zamora ${ }^{6}$, \\ Nataly Paz-Salas?
}

${ }^{1}$ ESPOL Polytechnic University, Escuela Superior Politécnica del Litoral, Centro de Investigación y Proyectos Aplicados a las Ciencias de la Tierra (CIPAT), Guayaquil, Ecuador

${ }^{2}$ ESPOL Polytechnic University, Escuela Superior Politécnica del Litoral, Facultad de Ingeniería Ciencias de la Tierra (FICT), Guayaquil, Ecuador

${ }^{3}$ Universidad Estatal Península de Santa Elena, Facultad de Ciencias de la Ingeniería, La Libertad, Ecuador

${ }^{4}$ ESPOL.Polytechnic University, Escuela Superior Politécnica del Litoral, ESPOL, Facultad de Ciencias Naturales y

Matemáticas (FCNM), Ecuador

${ }^{5}$ ESPOL.Polytechnic University, Escuela Superior Politécnica del Litoral, ESPOL, Geo-recursos y Aplicaciones (GIGA),

Ecuador.

${ }^{6}$ Universidad Politécnica de Madrid, Escuela Técnica Superior de Ingenieros de Minas y Energía, Spain

${ }^{7}$ BIRA Bienes Raíces S.A., Zaruma, Ecuador

Corresponding Author Email: pcarrion@espol.edu.ec

https://doi.org/10.18280/ijdne.150106

Received: 23 August 2019

Accepted: 20 November 2019

\section{Keywords:}

Ecuador, Geoparks, global heritage, sustainability, SWOT

\begin{abstract}
The Convention for the Protection of the Global, Cultural and Natural Heritage of 1972, arises from the need to identify some priceless and irreplaceable nation's assets. The first global natural heritage, recognized by UNESCO, was Galapagos Islands in 1978 and the first cultural heritage of humanity was Quito Historic Centre in the same year. Ecuador is the most compact megadiverse country, because it has four climatic regions at the same time: the amazing ocean's Coast, the Andean Highlands, the East- ern jungle and the insular wonder of Galapagos Islands; thus, assures us that we keep many assets, both natural and cultural. The aim of this article is to analyze the world heritages of Ecuador, and the possible candidates presented to UNESCO, with a matrix of SWOT analysis that allows us to set strategies that strengthen the current ones and lead for a greater achievement and awareness of this type of dignities. The methodology is based on the following steps: (i) Analysis and systematization of the existing information of the current world heritages of Ecuador, and the presented candidacies. (ii) Introduction to the new UNESCO designation called 'Geopark' in Ecuador and its impact, (iii) Realization of a SWOT analysis for the current world heritages in Ecuador and (iv) Proposal of strategies, through the SWOT matrix, for the strengthening, awareness and achievement of other assets. There are 1092 officially declared world heritages by UNESCO, Ecuador has eight. At the moment, Ecuador presented one Geopark candidacy and another five proposals to UNDP and five places were given candidacy to world heritage. This represents a set of places, values, but above all, humanity linked to this environment that offers a unique singularity and strengthens it due to its small territorial extension.
\end{abstract}

\section{INTRODUCTION}

On the interconnected world in which we live, preserving and conserving the biodiversity and the heritage assets that are found on our planet are the fundamental keys for the wellness of humanity, since those are the legacy we have received from the past, which we live in the present and that we will transmit to future generations [1]. Thanks to the support of the World Heritage Convention of 1972, it was established that the sites considered as global heritages are those places on earth that have exceptional universal value and are an irreplaceable source of life and inspiration [2]. Many are the countries that have ratified being part of this international community that fights in favor of identifying and protecting the most important natural and cultural heritage of our planet with the help of local communities, its work is considered an effective tool since it allows to address contemporary challenges related to climate change, uncontrolled urbanization, excessive mass tourism, socioeconomic and sustainable development of countries, but above all, unpredictable natural catastrophes [3]. Therefore, considering that patrimonies are signs of identity that characterize a place and exalt its beauty to the

world, it is essential to know the proper definition of these two important terms [4]. Cultural heritage can be defined [5] as an urban set of traditional construction and archaeological evidence or intangible resources such as traditions, expressions or popular expressions alive, where the assessment of them is very different in each region of the world since each presents its own criteria when establishing protection and appraisal measures; in the same way you can define the natural heritage as the set of elements that make up a landscape, physical and biological monuments and geological formations that have a unique value from the scientific point of view of conservation and natural beauty [6].

In Ecuador the heritage acts as a foundation on which the population builds its memory and develops its own identities 
[7] that require valuation [8], because it has several declarations of world heritage that began in 1978 where the UNESCO recognizes Quito as the first Cultural Heritage City of Humanity and recognizes the Galapagos Islands and the Sangay National Park as a Natural Heritage [9]. Later, in 1983, the historic downtown of Cuenca and Qhapac Nan were included within the cultural heritage and as intangible heritage the Zápara language, the traditional woven straw hats and Marimba music [10]. UNESCO and its desire to preserve the geological heritage with the help of non-governmental organizations from several member countries seeks to develop another complementary global network whose main goal is to promote a network of geological parks that are based on the interest shown by scientific institutions that seek rescue the spaces with a geographical continuity and landscapes of great geological relevance, where the holistic concept of protection, education and sustainable development is the one that stands out [11].

Therefore, every heritage asset recognized by UNESCO must have a development project based on its tourism promotion with very clear economic and development objectives, which highlight the protagonist and launch the initiatives of the Geo-preservation and dissemination of the site in order to comply with the principles that make this place the most suitable for the denomination 'Geopark' [12]. However, the term Geopark was included in Ecuador as one of the most important tools that seeks to increase the awareness of geo diversity, thus enabling the country to position itself as a reference of sustainable tourism in the world [13].

\section{STUDY OF THE ZONE}

Ecuador is located on the northwestern coast of South America on the torrid zone of the American continent; it has an area of 256,370 square kilometers bounded on the north by Colombia, on the south and east by Peru and on the west by the Pacific Ocean [14].

On all the extension from the north to the south the mountainous system of the Andes crosses thru Ecuador, this gives origin to the four natural regions that are: The Coast formed by fertile plains, sedimentary basins and elevations of low altitude; then the Sierra is sur- rounded by Andean peaks and pristine highlands with mountains and snowy peaks reaching 6,268 meters from where you can see large valleys [15]. The Amazon rainforest is undoubtedly the highest achievement of creation since it is a region full of an incomparable geodiversity considered as part of the lung of the planet and finally the enchanted islands 'Galapagos' that has a variety of endemic species and a great panorama full of flora and fauna that make it an almost unique island, where the famous scientist Charles Darwin, a lover of nature, was inspired to establish the theory of the evolution of species [16] (Figure 1).

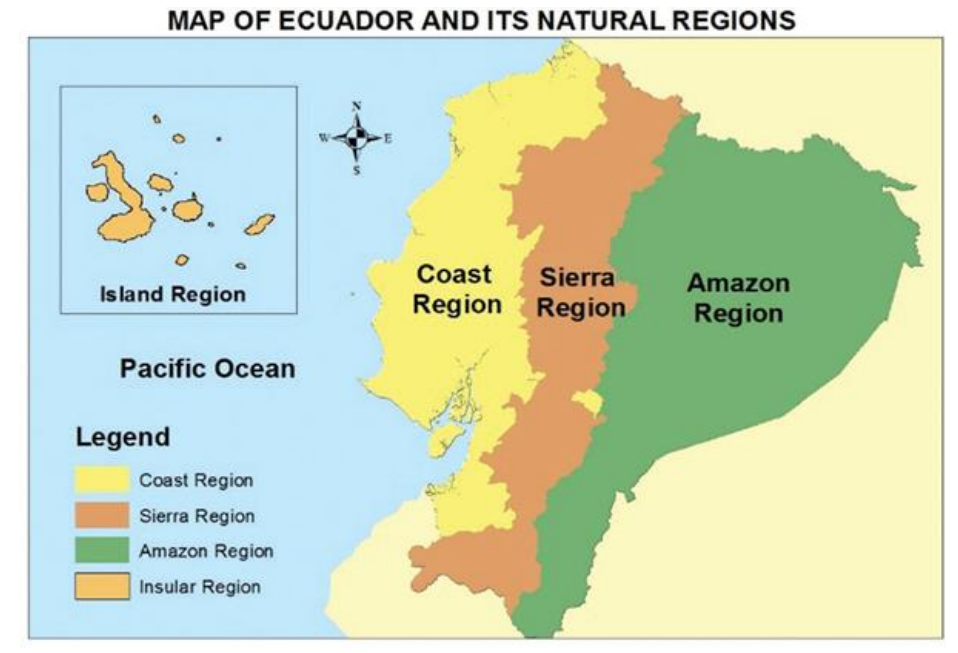

Figure 1. Ecuador and its four Natural Regions [17]

\section{OBJETIVES}

\subsection{General objective}

Analyze the world heritage of Ecuador and the possible candidates presented to UNESCO, through a matrix of analysis SWOT for the establishment of strategies that fortify the current ones and lead to a greater achievement and awareness of this type of dignities.

\section{METHODOLOGY}

The applied methodology to carry out this research work consists of four phases (Figure 2). (i) Phase I is based on carrying out an analysis and systematization of the information, compiling various bibliographic sources of the current world heritage of Ecuador, that were declared and recognized by UNESCO and the candidatures presented, in order to be able to know the characteristics that stand out in each one and to implement improvements.

(ii) Phase II introduces the new designation presented and named by UNESCO as 'Geopark' in Ecuador, where the causing impact in the regions of the country is deeply analyzed.

(iii) Phase III consists of preparing a SWOT analysis of Ecuador's world heritage together with government representatives, educational scientists and researchers, highlighting the positive critical factors that can be exploited as strengths and opportunities in the same way with the negative factors that must be eliminated or be reduced with the 
weaknesses and especially the external negative aspects that could obstruct the achievement of our objectives with the threats and in that way to know which are the needs that should be taken into account to further enhance the country's tourism. (iv) Finally, phase IV is based on a proposal of strategies based on the results obtained previously through SWOT matrix that allows the strengthening, awareness and achievement of other heritage assets [18].

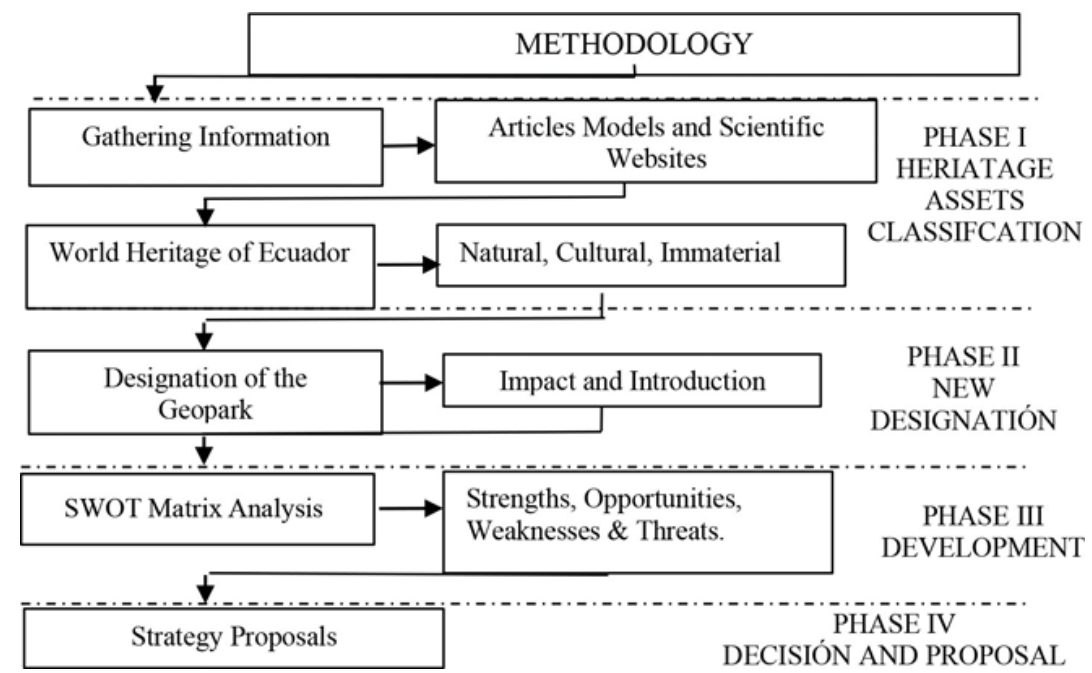

Figure 2. Scheme of the methodology used for the evaluation of Ecuador's world heritage assets

\section{DEVELOPMENT}

Between the coast and the mountains, between the highlands and the jungle is Ecuador, a country of narrow territory, but rich in natural beauty that keeps many world heritages recognized by UNESCO as a sample of its wide culture, landscape, and intangible resources that have made be aware that these fragile riches require policies and development models that allow them to be preserved, respected and conserved due to their great diversity and unique- ness, that is why there are eight world heritage declared by UNESCO and classified as cultural, natural and intangibles [19].

\subsection{Ecuador's world heritages}

Figure 3 and Table 1 detail the information of the eight existing world heritages, along with the dates in which they were designated and the denominations reached by each one.

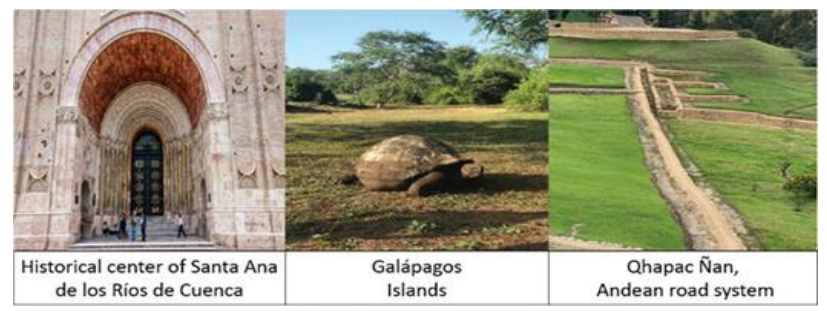

Figure 3. Photographs of the World Heritage of Ecuador recognized by UNESCO

Table 1. Characteristics of current Ecuador's world heritage

\begin{tabular}{|c|c|c|c|}
\hline Name & Class & Characteristics & Denomination \\
\hline $\begin{array}{c}\text { Centro histórico } \\
\text { de Santa Ana } \\
\text { de los Ríos de } \\
\text { Cuenca }\end{array}$ & $\begin{array}{c}\text { Cultural } \\
\text { Heritage } 1999\end{array}$ & $\begin{array}{l}\text { Existing buildings of colonial and republican style of } \\
\text { great architectural beauty }\end{array}$ & $\begin{array}{l}\text { The Atenas of Ecuador due to its } \\
\text { architecture, diversity and arts input }\end{array}$ \\
\hline $\begin{array}{c}\text { Centro Histórico } \\
\text { de Quito }\end{array}$ & $\begin{array}{c}\text { Cultural } \\
\text { Heritage } 1978 \\
\end{array}$ & $\begin{array}{l}\text { It has a natural, geographical, architectural and } \\
\text { culturally rich- ness in the extensive historic downtown. }\end{array}$ & $\begin{array}{c}\text { Historic downtown best } \mathrm{p} \\
\text { altered in Latin }\end{array}$ \\
\hline $\begin{array}{l}\text { Qhapac Nan, } \\
\text { Sistema vial } \\
\text { andino }\end{array}$ & $\begin{array}{c}\text { Cultural } \\
\text { Heritage } 2014\end{array}$ & $\begin{array}{c}\text { Pre-Hispanic vial path system of } 108.87 \mathrm{~km} \text { consisting } \\
\text { of } 49 \text { archaeological sites with indigenous, Afro- } \\
\text { Ecuadorian and mestizo communities [21]. }\end{array}$ & $\begin{array}{c}\text { Named the Inca Path in several countries } \\
\text { such as: Chile, Bolivia, Argentina, } \\
\text { Colombia, Peru and Ecuador }\end{array}$ \\
\hline Islas Galápagos & $\begin{array}{c}\text { Natural } \\
\text { Heritage } 1978\end{array}$ & $\begin{array}{l}\text { The archipelago of Galápagos is a true natural } \\
\text { laboratory of a great variety of endemic species. [22] }\end{array}$ & $\begin{array}{c}\text { UNESCO's National Park in 1959, } \\
\text { Biosphere Re- serve, Marine Reserve and } \\
\text { Whale Sanctuary. }\end{array}$ \\
\hline $\begin{array}{l}\text { Parque Nacional } \\
\text { Sangay } \\
\end{array}$ & $\begin{array}{c}\text { Natural } \\
\text { Heritage } 1983 \\
\end{array}$ & $\begin{array}{l}\text { It has an area of } 502,067 \text { hectares and constitutes one of } \\
\text { the protected areas with the greatest biological diversity. }\end{array}$ & $\begin{array}{c}\text { National Park of Ecuador, Sangay } \\
\text { Ecological Reserve in } 1975 \\
\end{array}$ \\
\hline Musica Marimba & $\begin{array}{c}\text { Intangible } \\
\text { Heritage } 2015 \\
\end{array}$ & $\begin{array}{l}\text { It is a representation of poems, stories in songs and } \\
\text { dances of Afro-Ecuadorian descendants. [21] }\end{array}$ & Named as a binational proposal. \\
\hline $\begin{array}{l}\text { Sombrero de paja } \\
\text { toquilla }\end{array}$ & $\begin{array}{c}\text { Intangible } \\
\text { Heritage } 2012 \\
\end{array}$ & $\begin{array}{c}\text { Sociocultural expression of heritage manufactured base } \\
\text { of braided palm leaves }\end{array}$ & The best hat made by craftsmen. \\
\hline Lengua Zápara & $\begin{array}{c}\text { Intangible } \\
\text { Heritage } 2008 \\
\end{array}$ & $\begin{array}{l}\text { It develops in the heart of the Amazon and is expressed } \\
\text { through myths and rituals. }\end{array}$ & $\begin{array}{l}\text { The Zápara language is considered as the } \\
\text { oral heritage of Humanity }\end{array}$ \\
\hline
\end{tabular}




\subsection{World heritage proposals}

Table 2 and Figure 4 and summarize the information in an organized manner to demonstrate the context of all candidacies presented to UNESCO before reaching the name of heritage.

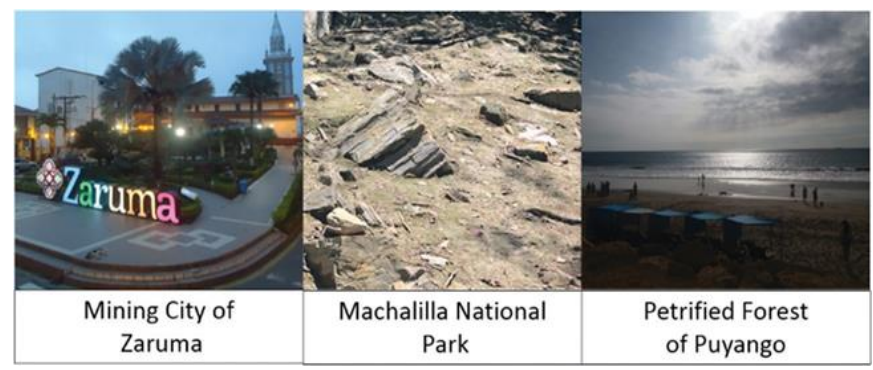

Figure 4. Photographs of the main places eligible for world heritage presented by Ecuador

\subsection{UNESCO global geoparks}

The declaration of a site as a Geopark is a recognition granted to regions that have geological heritage, but may also be of archaeological, ecological, historical or cultural interest that contribute to the sustainable development of the territories. For these reasons UNESCO Global Geoparks are mechanisms of international cooperation that help places considered as heritage to reach great value and seek conservation backed one another in conjunction with local communities to propose awareness of it. This declaration does not imply any regulations for the use of the territory, but it does imply the commitment to make investments for its conservation, tourism and didactic use, including access [20].

When a territory seeks to be a global Geopark, it must follow an established candidature and evaluation process where characteristics such as size is essential since it must be large enough to favor economic and cultural development, another important point is its management and participation to indicate the traits that are within the Geopark must be accessible to visitors.

Table 2. Characteristics of current Ecuador's world heritage

\begin{tabular}{|c|c|c|c|}
\hline Name & Class & Location & Characteristic \\
\hline $\begin{array}{l}\text { Parque Nacional } \\
\text { Machalilla }\end{array}$ & $\begin{array}{c}\text { Natural } \\
\text { and Cultural } \\
1998\end{array}$ & $\begin{array}{l}\text { It is located on the south coast } \\
\text { of the province of Manabí }\end{array}$ & $\begin{array}{l}\text { It is the only island park that comprehends two areas [23]. } \\
\text { Possessor of scenic tropical landscapes. }\end{array}$ \\
\hline Ciudad Minera de Zaruma & $\begin{array}{c}\text { Cultural } \\
\text { Heritage } 2016 \\
\end{array}$ & $\begin{array}{l}\text { It is located southeast in the } \\
\text { province of El Oro }\end{array}$ & $\begin{array}{l}\text { It has a neoclassical architecture influence [24]. } \\
\text { Their culture is reflected in customs, traditions. }\end{array}$ \\
\hline $\begin{array}{l}\text { Bosque Petrificado de } \\
\text { Puyango }\end{array}$ & $\begin{array}{c}\text { Natural } \\
\text { Heritage } 1998\end{array}$ & $\begin{array}{l}\text { It is located on the south region } \\
\text { between Loja y el Oro. }\end{array}$ & $\begin{array}{c}\text { It has a rich landscape with paleontological and } \\
\text { archaeological resources with remains of marine fossil } \\
\text { deposits }\end{array}$ \\
\hline $\begin{array}{l}\text { Ferrocarril Transandino de } \\
\text { Ecuador }\end{array}$ & $\begin{array}{c}\text { Cultural } \\
\text { Heritage } 2016\end{array}$ & $\begin{array}{l}\text { The railroad is located in } \\
\text { Guayaquil and Quito. }\end{array}$ & $\begin{array}{l}\text { It has an extension of } 452 \mathrm{Km} \text { that provides the tourist } \\
\text { with comfort, pleasant atmosphere, family and social } \\
\text { interaction [25]. }\end{array}$ \\
\hline $\begin{array}{l}\text { Parque Arqueológico } \\
\text { Mayo Chinchipe Marañón }\end{array}$ & $\begin{array}{c}\text { Cultural } \\
\text { Heritage } 2016\end{array}$ & $\begin{array}{l}\text { It extends along the } \\
\text { Hydrographic basin of Mayo- } \\
\text { Chinchipe }\end{array}$ & $\begin{array}{l}\text { Includes deposits belonging to the Mayo-Chinchipe } \\
\text { culture [26]. } \\
\text { Presents a range of paleontological evidences. }\end{array}$ \\
\hline
\end{tabular}

Table 3. Characteristics of the world heritage proposals that Ecuador has and that are currently in the process of acceptance

\begin{tabular}{|c|c|c|}
\hline \multicolumn{3}{|r|}{ Geopark Projects in Ecuador } \\
\hline Name & Status & Characteristic \\
\hline $\begin{array}{l}\text { Geopark Project } \\
\text { 'Imbabura' }\end{array}$ & $\begin{array}{l}\text { Accepted } \\
\text { in } 2019\end{array}$ & $\begin{array}{l}\text { The Imbabura Geopark project began in } 2015 \text { with the support of local agencies and research centers, } \\
\text { becoming known as the 'Imbabura Geopark' in session } 206 \text { of April } 172019 \text { thanks to the support of } \\
\text { regulatory agents who with a hard analysis achieved the designation promoting new geotourism } \\
\text { projects in the province [27]. }\end{array}$ \\
\hline $\begin{array}{l}\text { Geopark Project } \\
\text { 'Napo-Sumaco' }\end{array}$ & In Process & $\begin{array}{l}\text { The Napo Sumaco Geopark started with the support of Napo's Municipality, the administrative head } \\
\text { entity that in conjunction with the Ikiam Amazon Regional University, and it comprised of } 71 \text { sites of } \\
\text { geological, geomorphological, cultural and biological interest [28]. }\end{array}$ \\
\hline $\begin{array}{l}\text { Geopark Project } \\
\text { 'Ancón- Santa } \\
\text { Elena' }\end{array}$ & In Process & $\begin{array}{l}\text { The Ancón-Santa Elena Geopark project is promoted from the intellectual cradle of the Santa Elena } \\
\text { University, } \\
\text { which focuses on highlighting those Ancon geological and mining sites that deserve to be recognized, } \\
\text { conserved and preserved [12]. }\end{array}$ \\
\hline $\begin{array}{l}\text { Geopark Project } \\
\text { 'Volcán } \\
\text { Tungurahua' }\end{array}$ & In Process & $\begin{array}{l}\text { The Geopark Tungurahua project seeks to promote tour- ism by taking advantage of mountain activities } \\
\text { that can be done and can generate an opportunity for the development of investments on five cantons }\end{array}$ \\
\hline $\begin{array}{l}\text { Geopark Project } \\
\text { 'Ruta del Oro' }\end{array}$ & In Process & $\begin{array}{c}\text { The Ruta del Oro project seeks to conserve the cultural and historical legacy of its natural resources } \\
\text { such as geomorphological formations and landscapes that represent a strategy to potentiate the } \\
\text { sustainable development of the region. }\end{array}$ \\
\hline $\begin{array}{l}\text { Geopark Project } \\
\text { 'Galápagos' }\end{array}$ & In Process & $\begin{array}{l}\text { The Geopark Galapagos project is one of the most emblematic archipelagos in the world, being a site of } \\
\text { special relevance for UNESCO due to the variety of endemic and unique species as well as its } \\
\text { exuberant flora }\end{array}$ \\
\hline $\begin{array}{l}\text { Geopark Project } \\
\text { 'Jama-Pedernales' }\end{array}$ & In Process & $\begin{array}{l}\text { The Jama-Pedernales project compiles the mega diversity of natural resources such as flora, fauna and } \\
\text { geological and mining sites with great tourist potential found in the province of Manabí [29]. }\end{array}$ \\
\hline
\end{tabular}




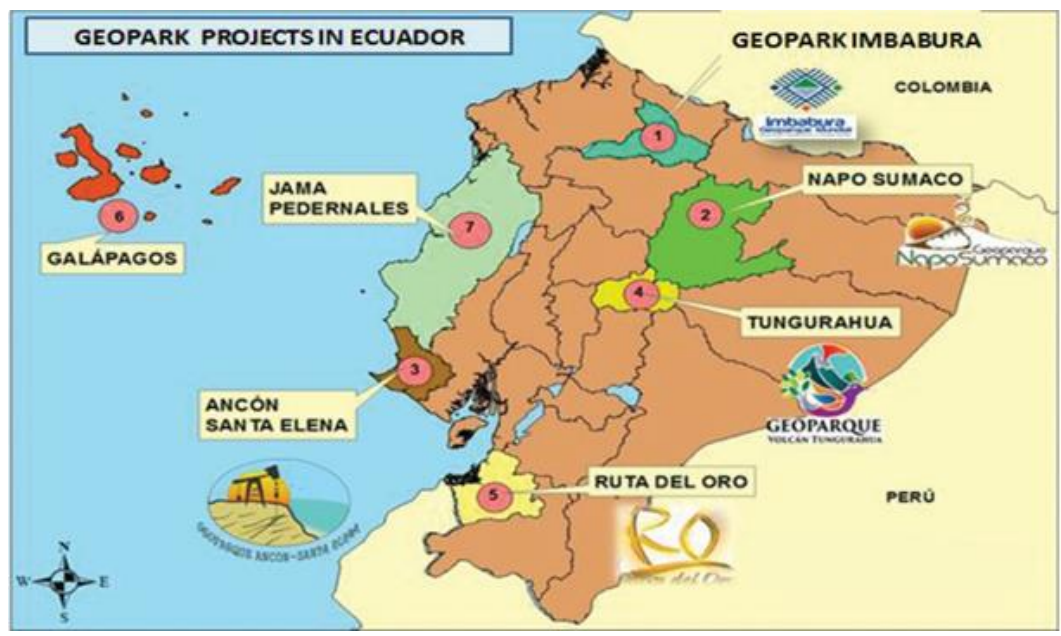

Figure 5. Geopark projects in process of acceptance and Geopark Imbabura currently designated by UNESCO [16]

The economic development that the site offers should have a direct impact in the area for the stimulation of small businesses and innovation initiatives, education is also rescued since through this organize activities and dissemination tools can be accomplishing to encourage the geoscientific knowledge to the public and mainly to promote scientific research where success will depend clearly on the contact between the managers and the community, since it is important for those places to benefit from the adequate protection measures following the legislation and nature conservation regulations of the country.

In Ecuador, the intention is to promote the idea of Geoparks with the desire to achieve international recognition of the beauties of their heritage sites; having in 2019 the most important result after several years of work Ecuador has the first Geopark in the province of Imbabura, however there are still more applications in progress that are the Napo-Sumaco Geopark Project, the Ancón-Santa Elena Geopark Project, Tungurahua Volcano Geopark Project, Ruta del Oro Geopark Project, Galapagos Geopark Project, and Jama-Pedernales Geopark Project (Table 3 and Figure 5).

\section{RESULTS}

\subsection{SWOT matrix analysis}

From the analysis in Table 4, it is evident that the SWOT analysis was carried out through the exchange of criteria and ideas with experts in the area of global heritage, where is highlighted the strengths of these eight characteristic sites, which have innumerable attractiveness both naturally and culturally and represent a real potential for tourism development, taking as opportunities the implementation of promotion and dissemination strategies to promote geotourism along with entities such as universities that seek to support projects that rescue and preserve heritage assets. The perspective of this topic for the youth and governmental entities are certain barriers that are present for the development of a place, such as the uncontrollable environmental degradation and the lack of culture, therefore threats must be considered as the most important and those should have an expedite consideration to care for and preserve the heritage that Ecuador has.

\subsection{Matrix of Strengths based on SWOT analysis}

From the analysis in Table 5, the following strategies are proposed and can be applied for the care and preservation of the spaces and heritage sites that Ecuador has.

(1) Planning government meetings with community entities and focal groups for the socialization and awareness of what it means to preserve a heritage site recognized by UNESCO, providing benefits and opportunities for development and assurance of their conservation.

(2) Creation of tourist proposals that guarantee economic growth and sources of employment with the determination of geo-routs thru the heritage sites in Ecuador, supporting them to have a significant enhancement of the attractions that those have and supported by govern- mental entities to involve the community.

(3) Provide incentives for the implementation of research and sustainable development projects through the support and international cooperation of public and private sector entities and universities.

Table 4. SWOT matrix analysis shows the context as evidence of the current status of the world heritages assets

\begin{tabular}{|c|c|}
\hline Strengths & Opportunities \\
\hline $\begin{array}{l}\text { 1. Potential for tourism } \\
\text { development } \\
\text { 2. Cultural and natural } \\
\text { attractions } \\
\text { Recognition worldwide } \\
\text { 3. Megadiversity and } \\
\text { natural wealth } \\
\text { 4. Representation and high } \\
\text { potential of folkloric } \\
\text { values. }\end{array}$ & $\begin{array}{l}\text { a. Promotion and dissemination of } \\
\text { heritage sites. } \\
\text { b. Geoturism development } \\
\text { c. Improvement of Access to tourist } \\
\text { circuits. } \\
\text { d. Scientific development through } \\
\text { connections with universities and } \\
\text { the private sector. } \\
\text { e. International cooperation }\end{array}$ \\
\hline Weaknesses & Threats \\
\hline $\begin{array}{c}\text { 1. Environmental } \\
\text { degradation } \\
\text { 2. Lack of cultural and } \\
\text { ignorance } \\
\text { 3. No articulated } \\
\text { promotion and } \\
\text { development processes } \\
\text { 7. Lack of government } \\
\text { policies } \\
\text { 5. Absence of tourists due } \\
\text { to lack of promotion }\end{array}$ & $\begin{array}{l}\text { a. Lack of resources to preserve } \\
\text { heritage assets. } \\
\text { b. Instability of trusted entities. } \\
\text { c. Weakening of cultural identify } \\
\text { by migratory flow. } \\
\text { d. Susceptibility of heritage sites }\end{array}$ \\
\hline
\end{tabular}


Table 5. Strategies formulated based on SWOT analysis matrix where solutions for the conservation and development of the heritage's sites are proposed

\begin{tabular}{|c|c|}
\hline Strengths + Opportunities & Strengths + Threats \\
\hline $\begin{array}{l}\text { 1.a.b Development of proposals } \\
\text { for Geoparks where the mega- } \\
\text { diversity of the heritage sites is } \\
\text { made known. } \\
\text { 3.d.e. Promote international } \\
\text { active cooperation, through } \\
\text { bilateral programs and initiatives } \\
\text { that arise between countries } \\
\text { aimed with better conservation of } \\
\text { natural, cultural and intangible } \\
\text { heritage. } \\
\text { 4.b.c Creation of geo-touristic } \\
\text { routes to cultural heritage sites to } \\
\text { potentiate the historical resource } \\
\text { so that resources are valued and a } \\
\text { great interest is generated by the } \\
\text { visitor to know the place. }\end{array}$ & $\begin{array}{l}\text { 3.c.b Both national and } \\
\text { international recognition of } \\
\text { the heritage assets through } \\
\text { cooperation with } \\
\text { government agencies } \\
\text { bracing the dialogue. } \\
\text { 2.a Development of } \\
\text { conservation and protection } \\
\text { plans that consist of } \\
\text { installation of information } \\
\text { panels that reflect the } \\
\text { specific information of each } \\
\text { point of interest }\end{array}$ \\
\hline Weakness + Opportunities & Weakness + Threats \\
\hline $\begin{array}{l}\text { 1.a.e Develop scientific and } \\
\text { technical studies and research, } \\
\text { perfecting intervention methods } \\
\text { that allows the nation to face the } \\
\text { dangers that threaten its Heritage. } \\
\text { 2.a.b Approach of focal groups to } \\
\text { give information about the } \\
\text { benefits of being recognized as } \\
\text { world heritage. } \\
\text { 5.c. Generate tourism projects } \\
\text { that serve as an alternative to } \\
\text { increase the profitability of the } \\
\text { population, which seeks to } \\
\text { promote an integrated and } \\
\text { sustainable tourism with the } \\
\text { cultural heritage and natural sites } \\
\text { that they have together with the } \\
\text { local population as a factor to } \\
\text { boost their values and social } \\
\text { identities. }\end{array}$ & $\begin{array}{l}\text { 2.c.d Implement activities } \\
\text { encompassing the } \\
\text { management plans adopted } \\
\text { for the regional heritage } \\
\text { areas and other conservation } \\
\text { actions in strategic } \\
\text { ecosystems, in an } \\
\text { articulated manner with the } \\
\text { territorial entities and the } \\
\text { local community. } \\
\text { 4.a Support of experts in } \\
\text { preservation and } \\
\text { conservation issues that } \\
\text { help heritage sites maintain } \\
\text { their status and improve } \\
\text { them if possible. }\end{array}$ \\
\hline
\end{tabular}

\section{ANALYSIS}

The analysis carried out with the support of several experts from various branches, it was established that in Ecuador there are denominations that acquire some of the sites that have unique and representative characteristics of the sectors where those are found, reflecting in an exclusive way the work carried out by the entities responsible for the dissemination of the heritage sites in order to make known to others the beauties of the country.

However, there are several sites considered as heritage where there is evidence of the lack of work and resources used to preserve those assets, fostering the weakening of cultural identity due to various factors such as environmental degradation, the lack of government policies and, above all, the unawareness.

An easy example of perception are the Galapagos Islands which receive hundreds of thou- sands of tourists each year, who come to know the wonderful routes full of geological resources and a great variety of biological diversity, while other sites such as the Sangay National Park that is less visited, although it contains the same amount of landscape resources available to tourists but has several aspects to improve such as access and route planning so that tourists can better navigate the site, so It is necessary to implement strategies that promote these sites to control the impact and achieve an equitable distribution of income to this mega-diverse country.

That is why in Ecuador around eighteen years have passed in order to postulate again to the tentative list of World Heritage sites recognized by UNESCO to the five places considered as candidates; this reflects the lack of interest in this subject by related institutions and especially the lack of general importance given by the Ecuadorian citizens. Therefore, seeking to establish strategies that help these sites to get recognition to become part of the beauties that the country possesses and helping towns to improve their economic and social development by preserving these goods for future generations.

\section{CONCLUSIONS}

The presented investigation in this document reveals that in Ecuador there are currently eight world heritage sites recognized by UNESCO, five nominations submitted for consideration and the first Geopark designated in April 2019 with the name of 'Imbabura Geopark', as it has demonstrated that owns natural, cultural and folkloric characteristics that represent an undeniable potential to increase the tourist development of the country taking advantage of the international recognition that has been granted. For the strengthening and consideration of this type of designations, it was proposed: The creation of tourism proposals that are created from a governmental structure and through direct interaction with the communities involved to establish a drive for the promotion and development of these places to promote awareness of identity so that investments and tourism development are propitiated.

Another more crucial strategy that must be implemented is the search for incentives to carry out research and sustainable development projects through the support and the international cooperation of public and private sector entities and universities.

\section{ACKNOWLEDGMENT}

To the ESPOL Polytechnic University research project "Registro de patrimonio geológico y minero y su incidencia en la defensa y preservación de la geodiversidad en el Ecuador.".

To the UPSE University Research Project "Proyecto Geoparque Peninsula de Santa Elena"

\section{REFERENCES}

[1] Mejía, A. (2014). Protección jurídica del Patrimonio Público, El patrimonio cultural como derecho: El caso ecuatoriano. Revista de derecho foro: protección jurídica del patrimonio público, 21(1): 5-26. https://doi.org/10.32719/26312484

[2] Alberruche del Campo, E., Marchán, C., Sánchez, A., Ponce, D., García, A. (2012). Guía. metodológica para la integración del Patrimonio Minero en la Evaluación de Impacto Ambiental. In: Alberruche del Campo, E., Marchán, C., Sánchez, A., Ponce, D. y García, A. (eds) Instituto Geológico y Minero de España, Madrid. 
[3] Ministerio Coordinador del Patrimonio. Introduccion al Patrimonio Cultural del Ecuador. http://www.amevirtual.gob.ec/wpcontent/uploads/2017/04/libro-introduccion-alpatrimonio-cultural.compressed-ilovepdfcompressed.pdf, accessed on Jan. 17, 2020.

[4] Orche, E. (2003). Puesta en valor del patrimonio geológico-minero: el proceso de adaptación de explotaciones mineras a parques temáticos. In: VillasBoas, R., González, A. (eds) Patrimonio Geológico y Minero en el context del cierre de minas. Instituto Geológico y Minero de España, Madrid. ISBN 85-7227$168-6$

[5] Romero, J.C. (2008). Convención para la Protección del Patrimonio Mundial Cultural y. Natural. Patrimonio Cultural y Natural, Investigación.

[6] Vélez, L. Patrimonio Natural y Cultural. http://viajesflamingo.com/sostenibilidad/PATRIMONI O_NATURAL_Y_CULTURAL.pdf, accessed on Feb. $12,2020$.

[7] Pena, P.J.M. (2013). El patrimonio cultural, bibliográfico y documental de la humanidad. Revisiones conceptuales, legislativas e informativas para una educación sobre patrimonio. Cuicuilco, 20(58): 31-58.

[8] Klassen, C. (2020). La Llegada Fortuita de Charles Darwin a las Islas Galápagos el 15 de septiembre de 1835. https://www.metropolitantouring.com/noticias- ecuadory-galapagos/la-llegada-fortuita-charles-darwin-las-islasgalapagos-15-septiembre-1835, accessed on Feb. 12, 2020.

[9] Carrión, P., Mata, J., Romero, P., Espinoza, T. (2012). Geoparque en Ecuador. Conference: Seminario Internacional sobre Patrimonio Geológico y Minero, Machala, Ecuador.

[10] Figueroa, F. (2005). El control del tráfico Ilícito de bienes culturales patrimoniales, normativa y participación legal de las instituciones públicas correspondientes. Master dissertation. Facultad de Seguridad y Desarrollo, Instituto de Altos Estudios Nacionales, Quito, Ecuador.

[11] Scientific and Cultural Organization (UNESCO). Protection of Mankind's Cultural Heritage Sites and Monument.

https://unesdoc.unesco.org/ark:/48223/pf0000131324, accessed on Feb. 12, 2020.

[12] Geoparque Napo Sumaco. Guía Espeleológica de la Provincia del Napo. https://www.researchgate.net/publication/321753426_G uia_Espeleologica_de_la_Provincia_del_Napo, accessed on Feb. 12, 2020.

[13] Cortéz, J. (2013). Los geoparques como entes de conservación vinculante: Geodiversidad, Biodiversidad y Patrimonio Cultural. Nature and Conservation, 6(1): 46-53. $\quad$ https://doi.org/10.6008/ESS19838344.2013.001.0003

[14] Aguirre, E. Geografía del Ecuador y sus regiones naturales.

http://www.edupedia.ec/index.php/temas/geografia/delecuador/regiones-naturales-del-ecuador, accessed on Feb. 12, 2020.

[15] Carrera, E. Región Sierra Ecuatoriana. http://www.ecuador-explorer.com/es/html/la-sierraecuatoriana.html., accessed on Feb. 12, 2020.

[16] Sevilla, A. (2016). On the Origin of Species and the
Galapagos Islands. In: Quiroga, D., Sevilla, A. (eds) Darwin, Darwinism and Conservation in the Galapagos Islands. The legacy of Darwin and its new applications. Springer, Switzerland. https://doi.org/10.1007/978-3319-34052-4

[17] National Secretary of Planning and Development and National Information System. National Geographic Atlas. http://sni.gob.ec/atlas-geografico-nacional-2013, accessed on Feb. 12, 2020.

[18] García, A., Carcavilla, L. (2013). Documento metodológico para la elaboración del Inventario Español de Lugares de Interés Geológico (IELIG). In: García, A. \& Carcavilla, L. (eds) Instituto Geológico y Minero de España, Madrid.

[19] Sandoval-Guerrero, L. (2017). Patrimonio cultural y turismo en el Ecuador. Tsafiqui, 9(1): 1-24. https://doi.org/10.29019/tsafiqui.v0i9.349

[20] Sevilla, A. (2018). The mystery of mysteries. The Galápagos Islands in Ecuador and the Work "The Origin of Species". Historelo.rev.hist.reg.local, 10(19): 121-156. https://doi.org/10.15446/historelo.v10n19.61461

[21] Colón, M. (2018). Propuesta de la inclusion del patrimonio intangible de la cultura afroecuatoriana como atractivo turístico del canton Guayaquil. Engineer dissertation. Facultad de Especialidades Empresariales, Universidad Católica Santiago de Guayaquil, Guayaquil, Ecuador.

[22] Rivas, F. (2010). Creación de una revista para incentivar el ecoturismo en la parte sur de Manabí, lugar en que se encuentra el Parque Nacional Machalilla. Engineer dissertation. Facultad de Comunicación Social, Universidad Estatal de Guayaquil, Guayaquil, Ecuador.

[23] Aguirre, K. (2014). Diagnóstico de patrimonios y atractivos del Cantón Zaruma Provincia de El Oro para su promoción turística enfocada en el turismo cultural. Engineer dissertation. Facultad de Especialidades Empresariales, Universidad Católica Santiago de Guayaquil, Guayaquil, Ecuador.

[24] Salvador, P. (2001). La rehabilitación de los ferrocarriles ecuatorianos. Master dissertation. Facultad de Seguridad y Desarrollo, Instituto de Altos Estudios Nacionales, Quito, Ecuador.

[25] Valdez, F. Primeras Sociedades de la Alta Amazonia de la Cultura Mayo Chinchipe-Marañón. https://horizon.documentation.ird.fr/exldoc/pleins_textes/divers17-07/010070442.pdf, accessed on Feb. 12, 2020.

[26] Sánchez-Cortez, J., Simbaña-Tasiguano, M. (2018). Los geoparques y su implantación en América Latina. Estudios Geográficos, 79(205). https://doi.org/10.3989/estgeogr.201817

[27] Secretaría Permanente del SELA. Políticas e instrumentos para enfrentar el impacto de la crisis económica internacional sobre las Pequeñas y Medianas Empresas (PYMES) de América Latina y el Caribe. http://www.redegarantias.com/fotos/editor2/REGAR/Ev entos/2009/di 609 politicas crisis economica sobre pymes.pdf, accessed on Feb. 12, 2020.

[28] Sánchez-Cortez, J.L., Arredondo-García, M.C., LeyvaAguilera, C., Ávila-Serrano, G., Figueroa-Beltrán, C., Mata-Perelló, J.M. (2017). Participación comunitaria y percepción social en Latinoamérica: un futuro para las áreas protegidas y proyectos de geoparques. Ambiente y Desarrollo, 21(41),

61-77. 
https://doi.org/10.11144/Javeriana.ayd21-41.pcps

[29] Álvarez, A. (2014). Proyecto Geoparque Ancón SantaElena.

https://es.scribd.com/document/251770107/Propuestadel-Geoparque-Ancon, accessed on Feb. 12, 2020.
NOMENCLATURE

UNESCO United Nations Educational, Scientific and Cultural Organization

SWOT Strengths, Weaknesses, Opportunities, and Threats

UNDP United Nations Development Programme 